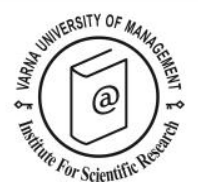

\title{
Profiling airport travellers based on their perceptions, satisfaction and intention to recommend food and beverage services
}

\author{
Giacomo Del Chiappa ${ }^{1 *}$, Marcello Atzeni ${ }^{2}$ and Salvatore Loriga ${ }^{3}$
}

Received: 28/09/2018 Accepted: 23/03/2019

\footnotetext{
${ }^{1}$ Department of Economics and Business, University of Sassari, Sardinia, Italy. Via Muroni, 25, 07100 Sassari, Italy. Phone: +390789 6421 84, Senior Research Fellow, School of Tourism \& Hospitality, University of Johannesburg, South Africa. E-mail: gdelchiappa@uniss.it

2 Department of Economics and Business, University of Cagliari, Sardinia, Italy.

3 Department of Economics and Business, University of Cagliari, Sardinia, Italy.

* Corresponding author

Coordinating editor: Stanislav Ivanov
}

\begin{abstract}
Consuming Food and Beverage is one of the most frequent non-aeronautical activities that passengers enjoy at airports and that significantly contributes to airport profitability. Despite this, there is still limited research aimed at analysing passengers' consumption behaviour of F\&B. With the aim to contribute to this somewhat under investigated research area, this study applies a factorcluster analysis on a sample of 1,139 airport travellers. Results from factor analysis reveal four underlying dimensions of F\&B perceptions (i.e. atmospherics, staff quality, value of money, product quality) and one dimension related to satisfaction and intention to recommend airport-based $F \& B$ services (i.e. "satisfaction and intention to recommend"). Cluster analysis applied to the scores of the five factors reveal that three clusters exist (i.e. "enthusiastics", "neutrals" and "price sensitives"). Chi-squared analysis tests show that significant differences exist based on socio-demographics (i.e. age, education level, employment status), travel-related variables (i.e. frequency of travelling) and flight-related variables (i.e. flying and check-in modality). Contributions to the theory, managerial implications and limitations to the study are discussed, and suggestions for further research are made.
\end{abstract}

Keywords: Socio-demographics, travel-related variables, flight-related variables, food and beverage services, airport, factor-cluster analysis.

Citation: Del Chiappa, G., M. Atzeni and S. Loriga (2019) Profiling airport travellers based on their perceptions, satisfaction and intention to recommend food and beverage services. European Journal of Tourism Research 23, pp. 172-190

\section{Introduction}

In the last two decades, the size of the tourism sector has been steadily increasing and the international arrivals rate has displayed an upward tendency, reaching a value of $6.8 \%$ in 2017 (WTTC, 2018). Tourism forecasts reveal that international arrivals are expected to reach

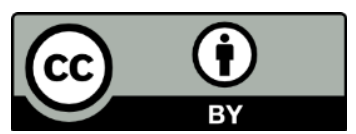

172
This work is licensed under the Creative Commons Attribution 4.0 International (CC BY 4.0). To view a copy of this license, visit https://creativecommons.org/licenses/by/4.0/ 
1.8 billion by 2030 (UNWTO, 2017). Tourism development is intrinsically linked with transportation, the airport system in particular. In 2017, the number of airport passengers worldwide increased by $7.9 \%$ (WTTC, 2018) and by the year 2040 it is estimated that the figure will reach 22.2 billion, from which one may determine a potential increase in airport food and beverage (F\&B) consumption along with that of retail services $(\mathrm{ACl}, 2017)$.

In the last few decades, airports have proven new proactive and marketing-driven approaches, with airports more often representing leisure, retail, and entertainment contexts (Jarach, 2001; Lin and Chen, 2013) pleasing the needs of different market segments (i.e. passengers and air transportation employees, tourists, residents, etc.) with an array of different value propositions, among which F\&B services are surely the most relevant (e.g. Doganis, 1992; Jarach, 2001). This metamorphosis has given rise to a situation where profitability of airports depends largely on non-aviation related activities (e.g. Graham, 2009; Fasone, Kofler and Scuderi, 2016; Yokomi, Wheat and Mizutani, 2017). According to $\mathrm{ACl}$ (2015), non-aeronautical revenue represented over $40 \%$ of airports' global profits. In 2010, non-aviation-related revenues accounted for $\$ 35$ billion, of which $\$ 10$ billion was generated by food and beverage services (hereafter, F\&B) (The Moodie Report, 2014). Consuming F\&B is one of the most frequent non-aeronautical activities that passengers enjoy at airports (CastilloManzano and López-Valpuesta, 2013; Echevarne, 2008). Lu (2014) reported that $40.7 \%$ of airport travellers buy food and beverages. By 2040, total annual airport passengers may reach 22.2 billion which will likely increase airports' F\&B and retail services' revenues $(\mathrm{ACl}, 2017)$.

This said, and as also stated by recent research (Halpern and Graham, 2003), it has become pivotal for both academics and practitioners to deepen their understanding about passengers' needs, their shopping behaviours and their satisfaction towards the different features of F\&B airport-based retail services (i.e. atmospherics, staff quality, product quality and value for money: Lo and
Qu; 2015; Sweeney and Soutar; 2001; Turley and Milliman, 2000). While current tourismrelated literature concurs that shopping is one of the most pervasive leisure activities that tourists enjoy while on their holidays (e.g. Correia and Kozack, 2016), limited research has analysed tourist behaviour with respect to retailing services (e.g. Choi, Law and Heo, 2018; Sirakaya-Turk, Ekinci and Martin, 2015); even less has been carried out to examine passengers' behaviours towards airport-based F\&B retailers (Del Chiappa, Martin and Román, 2016). Furthermore, academic research applying cluster analysis in order to profile consumers based on their level of satisfaction with different attributes of the F\&B services in airports is still - surprisingly - limited (Geuens, Vantomme and Brengman, 2004; Martinelli, 2012; Del Chiappa, Gimenez and ZapataAguirre, 2017), especially when considering their socio-demographic (e.g. age, gender, level of education, etc.) and travel-related characteristics (e.g. prior experience, length of stay, etc.). Quite surprisingly, no published papers exist examining the influence of flightrelated variables (e.g. check-in modality, frequency of flight, arrival time at the airport before departure). Hence, more studies on airports and on passenger consumer and expenditure behaviour at airports are needed (Moon, Yoon and Han, 2017).

This study was therefore carried out to widen the scientific debate devoted to investigate passengers' consumption behaviours pertaining to F\&B services in airport areas (Crawford and Melewar, 2003; Doong, Wang and Law, 2012). Thus, our findings contribute to deepen the scientific debate about this somewhat under-investigated research area considering a wider array of service attributes and of variables (sociodemographic, travelrelated and flight-related) potentially able to moderate the passengers' perceptions, satisfaction and intention to recommend. By doing so, the study provides useful information to airport managers attempting to increase the effectiveness of their retail marketing strategies aimed at fulfilling travellers' expectations (Shamma and Hassan, 2013).

The Olbia-Costa Smeralda International Airport, located in the northern part of Sardinia 
(due west of Rome and Naples), was selected as the research site to collect data. This airport is considered the main gateway to the Emerald Coast, one of Italy's most well-known and wellestablished luxury tourism destinations. Specifically, the study applies a factor-cluster approach to profile a sample of 1,139 travellers of Olbia with the aim to answer the following research questions:

RQ1: Are passengers homogeneous in term of their perceptions toward F\&B services at the Airport?

RQ2: Are passengers homogeneous in term of their satisfaction with $F \& B$ services at the Airport and their intention to recommend them to others?

RQ3: Do clusters differ among them based on the socio-demographics of respondents (i.e. age, gender, marital status, level of education, employment status, monthly household income and place of residence), travel-related characteristics (i.e. frequency of travel, frequency of flying) and flight-related variables (i.e. check-in modality, arrival time at the airport before departure)?

\section{Literature review}

According to Popovic, Kraal and Kirk (2010), overall airport experience can be defined as the wide array of activities and interactions that passengers have at the airport; these activities and interactions can be classified into two main categories: those needed to board the flight (the so-called necessary activities) and those that are discretionary in nature, such as shopping and dining.

Based on the utilitarian versus hedonic value dichotomy (Holbrook and Hirschman, 1982), a cornerstone of the retailing literature that needs to be considered when investigating any type of shopping behaviour is the distinction between hedonic and utilitarian motivations (e.g. Babin, Darden and Griffin, 1994; Sweeney and Soutar, 2001), and tourist shopping (i.e. the activity in which tourists participate while on holidays) is no exception (Gallarza et al., 2017). In fact, tourist shopping can be surely considered a holistic experience in which utilitarian, hedonic, social and emotional aspects simultaneously exist, providing tourists with a unique and entertaining local experience (e.g. Murphy et al., 2011). However, this experience has been less investigated in the context of airports despite the relevant role that non-aviationrelated revenues have in terms of airport profitability (e.g. Torres et al, 2005), with airports nowadays more frequently featuring leisure, experiential and retail contexts (e.g. Crawford and Melewar, 2003; Rowley and Slack, 1999; Wattanacharoensil et al., 2016; Wattanacharoensil et al., 2017).

According to Wattanacharoensil et al. (2017), airports are able to significantly influence travellers' experiences for several reasons. First, airports are a relevant tourism-related service encounter for people travelling to tourist destinations, with airport-based F\&B retailers symbolising and promoting the local identity and authenticity (e.g. Appold and Kasarda, 2006). Second, a good variety of food choices is considered the strongest predictor of overall passenger satisfaction (Bogicevic et al., 2013) and of the intention to revisit airport lounges (Han et al., 2012). According to Bogicevic et al. (2013), dining and shopping options are key dissatisfying factors in one's airport experience, meaning that poorly executed options cause dissatisfaction and complaints. However, they do not result in any compliments when performed well (e.g. Johnston, 1995). Third, airports are perceived by travellers as the first and last impression of a destination for visitors, the interpretative location of destination slogan and image, and integral part of their travelling experience (Wattanacharoensil et al., 2017).

In this scenario, commercial and retail outlets are more often cornerstones of the overall airport experience and crucial elements for any airport manager attempting to stimulate the hedonic experience and excitement of travellers (Ballantine, Jack and Parsons, 2010), to mitigate their travel-related stress and to generate a feeling of passengers' delight (Rowley and Slack, 1999). Chung (2015), for example, used a structural equation model to investigate the extent to which utilitarian and hedonic values are exerted on airport shopping behaviour (i.e. satisfaction and intention to recommend to others), and they found that the hedonic shopping values exert a stronger effect, suggesting that airport shopping involves more multisensory decisions than 
cognitive decisions. However, the hedonic and aesthetic aspect of the airport experience impresses air travellers only after fundamental experiences (i.e. functional experience and service personnel) reach a satisfactory level (Wattanacharoensil et al., 2017).

Studies on marketing concur that measuring customer satisfaction and behavioural intentions is certainly a fundamental criterion for companies in any sector, and hospitality and tourism are no exceptions (e.g. Pizam and Ellis, 1999; Torres, 2014). Airport travellers' satisfaction and behavioural intentions can be influenced by socio-demographic variables (e.g. age and gender), travel-related characteristics (e.g. purpose and frequency of travel, travel party size), flight-related variables (e.g. frequency of flying, wait time prior to embarkation), the airport and retailers' atmospherics and layout, service quality and value for money (Castillo-Manzano, 2010; Chen, Batchuluun and Batnasan, 2015; Chung, 2015; Del Chiappa, Martin and Román, 2016; Del Chiappa, Giménez and Zapata-Aguirre, 2017; Entwistle, 2007; Geuens, Vantomme and Brengman et al., 2004; Han, Yu and Kim, 2018; Lin and Chen, 2013; Moon, Yoon and Han, 2017; Namin, 2017; Newman and Lloyd Jones, 1999; Omar and Kent, 2001; Perng, Chow and Liao, 2010; Sacerdote, 2009). In particular, the airport and retailers' atmospherics, wayfinding and layout are relevant given their influence on the ease of passengers' orientation within the airport and their ability to identify the different facilities without feeling lost and disoriented, which in turn influence their actual likelihood to use facilities and to be satisfied (e.g. Lam et al., 2003).

The factors affecting customer satisfaction and behavioural intentions in the specific context of the F\&B sector are not simply related to the intrinsic characteristics of the food provided (e.g. quality, taste and variety) (e.g. Namin, 2017). Conversely, other relevant factors include aesthetics (e.g. interior design and layout and external appearance) and service encounters (i.e. the interaction between customer and service staff, and responsiveness and empathy) (e.g. Cao and Kim, 2015; Lin and Mattila, 2010). Furthermore, customer satisfaction and behavioural intentions with $F \& B$ services are influenced by socio-demographics of consumers (e.g. Lee, Cho and Ahn, 2012; Kim and Geistfeld, 2003). For example, Lee, Cho and Ahn (2012) reported that older consumers tend to be more satisfied and less concerned with price and taste compared to younger consumers, while women are more interested in staff responsiveness and service delivery compared to their male counterparts. In their study conducted in airport restaurants, Heung, Wong and Qu (2002) considered three perception factors ('employee attributes', 'reliability' and 'physical features') and showed that employee attributes were the most significant aspects shaping the overall satisfaction of airport travellers as well as their behavioural intentions.

Quite recently, the academic literature has started to investigate consumer preferences and satisfaction towards $\mathrm{F} \& \mathrm{~B}$ retailers in airports. Martinelli (2012) reported sociodemographics exerting a moderating effect on satisfaction. In her study, compared to men, women appeared to value retail services located closer to the boarding area, and were more sensitive to prices (when travelling for leisure reasons) and food quality (when travelling for business reasons). In their study, applying a fuzzy approach, Del Chiappa, Martin and Román (2016) reported that age was another moderating factor in airport travellers' satisfaction towards F\&B retailers; specifically, the authors reported older travellers as being less satisfied than their younger counterparts. Del Chiappa, Giménez and Zapata-Aguirre (2017) applied a multiple correspondence analysis, a hierarchical cluster analysis and a classification and regression tree to profile air travellers on the basis of their sociodemographic features (i.e. age, gender, education level, occupation, nationality), travelrelated variable (i.e. frequency of travel) and level of satisfaction against a list of 13 F\&Brelated items. According to these results, the authors concluded that airport travellers can be discriminated solely on the basis of age and occupation.

Nowadays, airports face fierce competition and their profitability is largely determined by nonaviation related activities, with F\&B-related revenues exerting a key role. As suggested by 
consumer behaviour literature (e.g. Cronin and Taylor, 1992), any attempts to assess and improve airport travellers' satisfaction and behavioural intentions towards $F \& B$ services in airports becomes pivotal (Cronin and Taylor, 1992). Hence, according to a relatively recent call for future research as well (Graham, 2008), it is certainly relevant to profile travellers based on their level of satisfaction (e.g. Lee, Lee and Wicks, 2004) towards F\&B services (as a whole or through an attributes-based view), possibly increasing the number of sociodemographic characteristics and travel- and flight-related variables used in the statistical analysis. Doing so would certainly contribute to broadening the scientific debate pertaining to the topic of $F \& B$ consumption in airports and could provide airport managers and retailers with useful information to be applied to effectively target their consumer segments. Despite this potential benefit, the existing literature aimed at examining the aforementioned area is limited and further research is needed in order to consider a wider number of F\&B-related service features and to investigate whether other socio-demographic characteristics and travel- and flight-related variables may be considered in order to be able to significantly moderate airport travellers' satisfaction and their behavioural intentions towards F\&B services. This study was carried out by presenting and discussing the results of a factor-cluster analysis conducted on a sample of 1,139 travellers who used F\&B services at the Olbia-Costa Smeralda International Airport.

\section{Method}

For purposes of this study, data collection was conducted at the Olbia-Costa Smeralda airport, the gateway to the Costa Smeralda (Emerald Coast), one of the most important and popular luxury destinations on the Mediterranean Sea. In 2017, the airport reached 2,808,323 million passengers, of whom around $48 \%$ were international ones.

The survey instrument was developed on the basis of existing studies and included two main sections. A qualifying question about whether respondents had consumed $F \& B$ related items was included at the beginning of the first part. Only people who answered positively were allowed to complete the questionnaire.
Respondents were then asked to reply to provide information about their sociodemographic profiles (e.g. age and gender), their travel-related habits (frequency of travel, purpose of travel, etc.) and flight-related habits (e.g. check-in modality and waiting time at the airport prior to flight departure). In the second section, respondents were asked to assess their level of agreement with 27 items specifically selected to measure atmospherics, staff quality, product quality, value for money, satisfaction and intention to recommend to others (both online and offline) of the F\&Brelated retail services they experienced (e.g. bars, fast food joints, restaurants and pizzerias). Specifically, the list of items used to measure aesthetics (12 items) was framed on the basis of the existing literature (e.g. Turley and Milliman, 2000) and redefined or adapted by consulting a group of airport managers and retailers working at Olbia-Costa Smeralda airport, thus allowing a theory-in-use approach (Zaltman, LeMasters and Heffring, 1982). Staff quality and product quality were measured by items sourced from Lo and Qu (2015) and adapted to suit the context of airport retailers (seven items for service quality and two for product quality). Value for money was measured using three items sourced from Sweeney and Soutar (2001). Satisfaction (one item) and intention to recommend to others (two items) were sourced and adapted from Jones and Reynolds (2006) and Zeithaml, Bitner and Dremler (1996). Satisfaction was measured by a single item as it often happens in the existing literature related to different fields and research settings in which retail is included (Ballantine, 2005; Zhou, 2004). A 5point Likert scale was used to indicate respondents' answers ( $1=$ I strongly disagree, $5=$ I strongly agree).

The questionnaire was originally designed in Italian, but since different nationalities could appear in a sampling process with tourists, three questionnaires were prepared by two professional translators (English, German and Italian). A back-translation method was adopted to guarantee quality assurance (e.g. Seddighi, Nutall and Theocharous, 2001). A pilot test with 20 travellers from the abovementioned three nationalities was conducted to assure the comprehensibility of 
the questions. No concerns emerged in these pilot tests. Hence, the three final questionnaires were considered definitive.

The data collection was carried out with the support of the airport management who was particularly prone in doing this given their long tradition in supporting research activities run by the University staff, and because of their interest in obtaining marketing insights from the study to be used to further improve their F\&B services. Three interviewers firstly undertook a security training section, directly delivered by the airport staff, to obtain the permission to entry the boarding area to interview passengers. Furthermore, the interviewers were subject to a training jointly delivered by the Human Resources Department of the Airport and one of the researchers responsible for leading the research team; this training aimed to train interviewers about when and how to approach passengers and how to support them in filling the survey without interfering in their assessment. Directly supervised by one of the authors, the three trained interviewers collected data face-to-face by intercepting 2,500 individuals in the boarding area from May to October 2015. On an average, the interviewers had access to the boarding area twice a week during specific time frames; this was done in accordance with the airport management necessities so as not to interfere with other marketing research and activities directly conducted by the airport staff. Only individuals aged 18 years and above who had tried F\&B services at the airport were asked to participate in the study. At the end of the data collection, a convenience sample of 1,139 complete questionnaires was collected (response rate: $45.56 \%$ ).

\section{Results}

Respondents were mostly middle-aged (35-44 years old: $21.0 \%$; 45-54 years old: $19.9 \%$ ) females $(63.2 \%)$, married or cohabiting $(55.4 \%)$, with a university degree $(41.0 \%)$, employed (42.2\%) and with an annual household income under $€ 15,000(24.2 \%)$ or over $€ 50.000$ (23.0\%). Respondents were mostly international travellers (52.1\%), travelling up to four times per year $(61.0 \%)$, mostly for leisure purposes (91.8\%), flying up to four times a year (68.5\%). Interviewees mostly arrived at the airport 1.5-2 hours before the flight's departure (43.9\%).

Overall, the respondents were reported to be satisfied with airport-based $F \& B$ services $(M=$ 3.71). Airport travellers were particularly satisfied with aesthetics and scored high on items such as 'The F\&B-related retailers have good standards of cleanliness' $(M=4.03)$, 'The lighting is appropriate and pleasant' $(M=3.96)$, 'The windows look good' $(M=3.91)$, 'The aesthetic and architectural aspect of the F\&Brelated retailers is pleasant and appealing' $(M=$ 3.87), 'The F\&B-related retailers have a good layout' $(M=3.87)$ and 'The decoration inside the F\&B-related retailers is pleasant and appealing' $(\mathrm{M}=3.86)$. Respondents were satisfied with staff quality and scored high on items such as 'In general, the staff has an aesthetic and smart appearance and dress' (M = 4.06); 'In general, the staff were courteous, polite and respectful' $(M=3.98)$ and 'The staff shows competence (knowledgeable and experienced)' ( $\mathrm{M}=3.93)$. Relatively high satisfaction levels were reported also for product quality, with respondents scoring high on items such as 'The quality of food and beverage is appropriate' $(M=3.65)$ and 'The variety of the offer for food and beverage is appropriate' $(\mathrm{M}=3.63)$. Overall, a neutral position was reported to exist in terms of value for money, with airport travellers scoring relatively low on items such as 'Prices of food and beverage of this airport are competitive with other airports' $(M=3.23)$, 'The products have a good quality/price ratio' $(M=3.22)$ and 'Prices are reasonable' $(M=3.02)$. Finally, respondents were reported to be slightly prone to spread a positive word-of-mouth (WOM) advertising, with traditional WOM being more likely to occur than electronic WOM (traditional WOM: $M=3.32$; eWOM: $M=3.12$ ).

For this study, we adopted a factor-cluster approach (Hair et al., 2010). Hence, an explorative factor analysis (principal component analysis and varimax rotation) was used to reveal underlying factors in the dataset. Five factors were extracted explaining $71.20 \%$ of total variance (Table 1). The Kaiser-Myer-Olkin index (0.954) and the Bartlett's test of sphericity (chi-square $=14,959.24 ; \quad p$ - value 
Profiling airport travellers based on their perceptions, satisfaction and intention to recommend food and beverage services.

Table 1. Factor analysis

\begin{tabular}{|c|c|c|}
\hline \multicolumn{3}{|c|}{ Factor 1: Atmospherics } \\
\hline A1 & The windows look good & 0.654 \\
\hline A2 & The lighting is appropriate and pleasant & 0.682 \\
\hline A3 & $\begin{array}{l}\text { The F\&B-related retailers have a good } \\
\text { lavout (arrangement of space) }\end{array}$ & 0.707 \\
\hline A4 & The background music is pleasant & 0.53 \\
\hline A5 & The temperature is pleasant & 0.706 \\
\hline A6 & $\begin{array}{l}\text { The F\&B-related retailers have good } \\
\text { standards of cleanliness }\end{array}$ & 0.724 \\
\hline A7 & The scents that you breathe are pleasant & 0.731 \\
\hline A8 & The noise is tolerable & 0.691 \\
\hline A9 & $\begin{array}{l}\text { The signs (to identify areas of products, } \\
\text { etc.) are understandable } \\
\text { The aesthetic and architectural features }\end{array}$ & 0.664 \\
\hline A10 & $\begin{array}{l}\text { of the F\&B-related retailers are pleasant } \\
\text { and appealina } \\
\text { The F\&B-related retailers are made so as }\end{array}$ & 0.71 \\
\hline A11 & $\begin{array}{l}\text { to effectively manage the movement of } \\
\text { people } \\
\text { The decorations inside the F\&B-related }\end{array}$ & 0.676 \\
\hline A12 & $\begin{array}{l}\text { retailers (colours, furniture, etc.) is } \\
\text { pleasant and appealing }\end{array}$ & 0.705 \\
\hline
\end{tabular}

Factor 2: Staff quality

2.159

0.793

A13 The staff responds to customer demand accurately and reliably

A14 The staff responds to customer inquiries in a timelv manner

A15 The staff is present, available and can be easily contacted

A16 In general, the staff was courteous, polite and respectful

The staff is able to communicate in a clear

A17 and understandable manner in a foreign lanquaqe

A18 In general, the staff has an aesthetic and smart appearance and dress

A19 The staff shows competence (knowledqeable and experienced)

Factor 3: Value for money

A20 Prices are reasonable

7.31

63.15

A21 Prices of food \& beverage of this airport are competitive with other airports

A22 The products have a good quality/price ratio

Factor 4: Product quality

A23 The variety of offer for food \& beverage is

A23 appropriate

A24 The quality of food and beverage is appropriate

Factor 5: Satisfaction and intention to recommend

A25 Overall, I am satisfied with the food and beveraqe services at this airport

I will speak well of the services of food and

A26 beverage of this airport to family and friends offline

I will speak well of the food and beverage

A27 services in this airport to family and friends on social media (Facebook, Twitter. Tripadvisor, etc.)

7.99

55.84

0.832

0.803

0.825

0.798

0.743

0.766

0.866

0.839

0.843

1.109

4.11

67.26

0.79

0.759

0.406

0.814

0.873
$\%$ variance \% variance Cronbact

explained cumulated Alpha

$\mathbf{4 7 . 8 5} \quad \mathbf{4 7 . 8 5 2}$

0.935

0.952

0.866

$\begin{array}{llll}1.064 & 3.94 & 71.2 & 0.864\end{array}$

Goodness of fit: Chi-square $=14959.24$ d.f. $=351 \mathrm{Sig}=0.000-K M O=0.954$ 
$<0.0001$ ) both confirm that the results appropriately explain the data. Cronbach's alpha was then calculated to test the reliability of the extracted factors; all values are 0.86 or higher, suggesting that the factors are reliable (Table 1).

The first factor is labelled 'atmospherics' (47.85\% of total variance) and results strongly correlated with items related to retail layout, architectural characteristics, decoration, cleanliness, sounds, lighting, etc.

'Staff quality' (7.99\% of total variance) includes items measuring perceived staff quality (e.g. accuracy and reliability, responsiveness, courtesy, language skills, etc.). 'Value for money' $(7.30 \%$ of total variance) is related to items devoted to measure airport travellers' perception in terms of the quality/price ratio and price appropriateness, also when compared to F\&B services in other airports. 'Products quality' (4.11\% of total variance) includes two items measuring perceived quality and the variety of F\&B offerings. The fifth and last factor is 'Satisfaction and intention to recommend' (3.94\% of total variance) and includes items measuring satisfaction and intention to recommend (both offline and online).

The scores of the five principal components were entered into a cluster analysis. Following Hair, et al. (2010), a double step method was used. A hierarchical cluster (Ward methodManhattan distances) was performed and three groups emerged. Then, a non-hierarchical method ( $k$-means) was applied to factor scores defining three different groups of airport travellers. Based on the analysis/interpretation of the mean scores that each group of passengers expressed towards the different items included in the survey, the three clusters were labelled as follow: 'Enthusiastics' (individuals who scored very high towards the different F\&B attributes/factors, in their overall satisfaction and particularly prone to recommend F\&B services to others, both offline and online), 'Neutrals' (individuals who scored on average around three or slightly higher with all the items, thus expressing a kind of neutral position) and 'Price sensitives' (who scored, on the whole, lower than counterparts in the items related of "value for money", thus suggesting to be more sensitive to price).

Table 2 shows the socio-demographic features, travel-related and flight-related characteristics of each cluster. The 'Enthusiastics' were the biggest cluster ( $N=627)$, including mostly middle-aged females (55.6\%) belonging to the $35-44(21.2 \%)$ or $45-54(23.2 \%)$ age brackets, married or cohabiting $(56.5 \%)$, with a high school diploma or better (42.2\%), being employed (43.8\%), with an annual household income over $€ 50,000$ (25.7\%).

'Enthusiastics' are mostly international airport travellers $(53.8 \%)$, travelling $(63.6 \%)$ and flying $(70.65 \%)$ up to four times per year mostly for leisure purposes (92.8\%). They were reported arriving at the airport 1.5-2 hours before their flight's departure $(41.6 \%)$ and handling their check-in face to face (50.1\%).

'Neutrals' ( $\mathrm{N}=267$ ) includes mostly young females $(62.0 \%)$ belonging to the 18-24 $(16.5 \%)$ or $25-34(30.1 \%)$ age brackets, married or cohabiting $(51.7 \%)$, with a university degree $(47.3 \%)$, being employees $(43.5 \%)$, reporting annual household income falling in the $€ 15,000-24,999$ span $(22.4 \%)$ or higher than $€ 50,000 \quad(23.0 \%)$. They are mostly international visitors $(50.8 \%)$, travelling up to four times $(54.3 \%)$ or five to ten times per year $(32.1 \%)$, mostly for leisure purposes $(94.4 \%)$. Neutrals are reported flying up to four times per year $(62.8 \%)$ and arriving at the airport $1.5-2$ hours before the flight departure (42.4\%); they mostly check in face-to-face $(66.2 \%)$.

'Price sensitives' was the smallest segment ( $\mathrm{N}$ $=245$ ) and included mostly middle-aged females $(57.1 \%)$ belonging to the 35-44 $(28.9 \%)$ or $45-54(18.5 \%)$ age groups, married or cohabiting $(57.4 \%)$, with a high school diploma $(38.5 \%)$ or a university degree (36.8\%), working as employees (37.7\%), with an annual household lower than $€ 15,000$ (29.1\%). Individuals belonging to this cluster are national $(50.0 \%)$ and international airport travellers $(50.0 \%)$, travelling up to four times per year $(63.0 \%)$ mostly for leisure reasons $(93.1 \%)$. They were reported to fly up to four times a year $(70.0 \%)$, arriving at the airport 1.5-2 hours before their flight's departure $(50.4 \%)$ and checking-in face-to-face (58.0\%). 
Profiling airport travellers based on their perceptions, satisfaction and intention to recommend food and beverage services.

Table 2. Socio-demographics and travel- and flight-related characteristics of clusters

\begin{tabular}{|c|c|c|c|c|}
\hline & $\begin{array}{l}\text { Neutrals } \\
\%\end{array}$ & $\begin{array}{l}\text { Enthusiastics } \\
\%\end{array}$ & $\begin{array}{l}\text { Price sensitives } \\
\%\end{array}$ & $\begin{array}{l}\text { Total } \\
\%\end{array}$ \\
\hline \multicolumn{5}{|l|}{ Gender } \\
\hline Male & 38.0 & 44.4 & 42.9 & 42.3 \\
\hline Female & 62.0 & 55.6 & 57.1 & 57.7 \\
\hline \multicolumn{5}{|l|}{ Aqe } \\
\hline $18-24$ & 16.5 & 13.6 & 21.0 & 16.2 \\
\hline $25-34$ & 30.1 & 24.8 & 23.9 & 26.0 \\
\hline $35-44$ & 22.6 & 21.2 & 28.9 & 21.0 \\
\hline $44-54$ & 15.0 & 23.2 & 18.5 & 19.9 \\
\hline $55-64$ & 12.0 & 11.4 & 9.1 & 11.0 \\
\hline$=65$ & 3.8 & 5.8 & 8.6 & 5.9 \\
\hline \multicolumn{5}{|l|}{ Marital status } \\
\hline Sinqle & 24.0 & 23.1 & 19.7 & 22.5 \\
\hline Enqaqed & 19.5 & 15.4 & 19.3 & 17.4 \\
\hline Married/cohabiting & 51.7 & 56.5 & 57.4 & 55.4 \\
\hline Widow & 1.1 & 1.8 & 1.6 & 1.6 \\
\hline Divorced & 3.7 & 3.2 & 2.0 & 3.1 \\
\hline \multicolumn{5}{|l|}{ Level of education } \\
\hline Primarv school & 1.5 & 0.9 & 1.2 & 1.2 \\
\hline Secondary school & 4.2 & 4.8 & 8.7 & 5.6 \\
\hline High school & 28.1 & 42.2 & 38.5 & 37.6 \\
\hline Universitv dearee & 47.3 & 39.8 & 36.8 & 41.0 \\
\hline Master's deqree & 13.5 & 8.9 & 13.6 & 11.2 \\
\hline Other & 5.4 & 3.4 & 1.2 & 3.4 \\
\hline \multicolumn{5}{|l|}{ Employment status } \\
\hline Emplovee & 43.5 & 43.8 & 37.7 & 42.2 \\
\hline Retired & 3.8 & 5.9 & 9.4 & 6.2 \\
\hline Housewife & 4.2 & 5.3 & 6.1 & 5.2 \\
\hline Manaqer/executive & 8.3 & 10.7 & 5.3 & 8.8 \\
\hline Occasional worker & 1.9 & 1.0 & 1.6 & 1.4 \\
\hline Student & 15.2 & 10.3 & 16.7 & 13.1 \\
\hline Freelancer & 17.0 & 13.7 & 11.8 & 14.1 \\
\hline Unemploved & 0.4 & 1.6 & 2.0 & 1.4 \\
\hline Other & 5.7 & 7.7 & 9.4 & 7.6 \\
\hline \multicolumn{5}{|c|}{ Annual Household income $(€)$} \\
\hline$<15.000$ & 19.1 & 24.9 & 29.1 & 24.2 \\
\hline $15.000-24.999$ & 22.4 & 16.9 & 17.7 & 18.6 \\
\hline $25.000-34.999$ & 19.7 & 19.2 & 16.3 & 18.7 \\
\hline $35,000-49,999$ & 15.8 & 13.3 & 20.6 & 15.5 \\
\hline$>50.000$ & 23.0 & 25.7 & 16.3 & 23.0 \\
\hline \multicolumn{5}{|c|}{ Yearlv frequency of travelling } \\
\hline $1-4$ & 54.3 & 63.6 & 63.0 & 61.0 \\
\hline $5-10$ & 32.1 & 24.2 & 21.8 & 25.7 \\
\hline$>10$ & 13.6 & 12.2 & 15.2 & 13.3 \\
\hline \multicolumn{5}{|l|}{ Yearlv frequency of flying } \\
\hline $1-4$ & 62.8 & 70.6 & 70.0 & 68.5 \\
\hline $5-10$ & 25.6 & 21.3 & 17.3 & 21.4 \\
\hline$>10$ & 11.6 & 8.1 & 12.7 & 10.1 \\
\hline \multicolumn{5}{|l|}{ Purpose of travelling } \\
\hline Leisure & 94.4 & 93.8 & 93.1 & 93.8 \\
\hline Business & 5.6 & 6.2 & 6.9 & 6.2 \\
\hline \multicolumn{5}{|c|}{ How long before the flight departure did vou arrive at the airport? } \\
\hline $30-45$ minutes & 3.8 & 3.0 & 3.3 & 3.3 \\
\hline $45-60$ minutes & 24.6 & 26.9 & 20.2 & 24.7 \\
\hline $1-1.49$ hours & 7.2 & 7.2 & 8.3 & 7.5 \\
\hline $1.5-2$ hours & 42.4 & 41.6 & 50.4 & 43.9 \\
\hline more than 2 hours & 22.0 & 21.3 & 17.8 & 20.6 \\
\hline \multicolumn{5}{|l|}{ Check-in modality } \\
\hline Traditional (face-to-face) & 66.2 & 50.1 & 58.0 & 56.2 \\
\hline Online & 33.8 & 49.9 & 42.0 & 43.8 \\
\hline \multicolumn{5}{|l|}{ Place of residence } \\
\hline Sardinia & 11.6 & 8.0 & 11.9 & 9.9 \\
\hline Italv & 37.6 & 38.2 & 38.1 & 38.0 \\
\hline Foreian countries & 50.8 & 53.8 & 50.0 & 52.1 \\
\hline
\end{tabular}


Table 3 describes each cluster based on airport travellers' perceptions towards F\&B retailers' atmospherics, staff quality, service quality and value for money.

'Enthusiastics' score high in term of atmospherics (e.g. 'The F\&B-related retailers have good standard of cleanliness': $M=4.27$ 'The lighting is appropriate and pleasant': $M=$ 4.24-'The windows look good': $M=4.20-$ 'The aesthetic and architectural aspects of F\&Brelated retailers are pleasant and appealing': $M$ $=4.21$ ), staff quality (e.g. 'The staff has an aesthetic and smart appearance and dress': M $=4.39$-'The staff was courteous, polite and respectful': $M=4.33$ - 'The staff shows competence': $M=4.32$ ), and product quality (e.g. 'The variety of offer for food and beverage is appropriate': $M=4.06$-'The quality of food and beverage is appropriate': $\mathrm{M}=4.04$ ). However, they seem to express some concerns in term of value for money and score just slightly positively towards items such as: 'Prices are reasonable': $M=3.38$ - 'The products have a good quality/price ration': $M=$ 3.55 - 'Prices of food and beverage of this airport are competitive with other airports': $M=$ 3.60). However, overall, they show a high level of satisfaction ( $\mathrm{M}=4.24)$ and intention to recommend to others (offline: $M=4.26$, online: $M=4.11)$.

'Neutrals' seem to show a neutral position towards the most part of the items (all the mean values are $\simeq 3$ ). However, they appear to be quite concerned in term of value for money, thus scoring lower than three with items such as 'The product has a good quality/price ratio' $(\mathrm{M}=2,86)$ and 'Prices are reasonable' $(\mathrm{M}=$ 2.70). Overall, they are neither satisfied or satisfied ('Overall I am satisfied with the food and beverage services at this airport': $M=$ 3.00) and do not appear actually willing to recommend $F \& B$ services at the airport to others, neither offline $(M=2.86)$ or online $(M=$ 2.76).

Even if at a lower level compared to 'enthusiastics', 'price sensitives' have positive view towards atmospherics, staff quality and product quality (all the mean value are $\simeq 4$ or slightly higher for atmospherics and staff quality and are $\simeq 3$ or slightly higher for product quality). However, when compared to both 'enthusiastic' and 'neutrals', they reported the strongest concerns in term of value for money of F\&B offer at the airport. In fact, 'price sensitives' score low or really low with items such as: 'The products have a good quality/price ratio' ( $M=2.95$ ), 'Prices of Food and Beverage of this airport are competitive with other airports' $(M=2.83)$ and 'Prices are reasonable' $(M=2.61)$. Overall, they reported a slightly positive level of satisfaction $(\mathrm{M}=3.43)$, but surprisingly they scored the lowest mean value in terms of intention to recommend to others (offline: $M=2.01$, online: 1.61 ) when compared to individuals in the other two clusters.

Finally, a series of chi-square tests $\left(X^{2}\right)$ were conducted to ascertain whether significant differences existed among the clusters based on socio-demographic and travel- and flightrelated variables (Table 4).

The results revealed that significant differences exist between the segments in terms of age $\left(X^{2}\right.$ $=21.189, p=0.020)$, education levels $\left(x^{2}=\right.$ 30.328, $p=0.001)$, employment status $\left(X^{2}=\right.$ $29.855, \quad p=0.019$ ), yearly frequency of travelling $\left(X^{2}=9.844, p=0.043\right)$, yearly frequency of flying $\left(X^{2}=9.700, p=0.046\right)$ and check-in modality $\left(X^{2}=18.450, p=0.000\right)$. No significant differences were reported to exist in terms of gender $\left(X^{2}=2.995, p=0.228\right)$, marital status $\left(X^{2}=6.254, p=0.619\right)$, monthly household income $\left(X^{2}=13.230, p=0.104\right)$, purposes of travelling $\left(X^{2}=0.385, p=0.825\right)$, arrival time at the airport before their flight's departure $\left(X^{2}=7.891, p=0.444\right)$ and place of residence $\left(X^{2}=4.141, p=0.387\right)$.

Overall, our results confirm some prior studies while rejecting others, as well as adding some completely new and fresh knowledge to further deepen the scientific debate devoted to analysing airport travellers' usage behaviours of $F \& B$ services.

For example, the fact that airport travellers' views towards different F\&B service features and their satisfaction levels were reported to be the lowest for 'neutrals' which is the segment with the highest number of women $(62.0 \%)$, which seems to confirm that women tend to 
Profiling airport travellers based on their perceptions, satisfaction and intention to recommend food and beverage services.

Table 3. Cluster analysis

\begin{tabular}{|c|c|c|c|c|}
\hline & $\begin{array}{l}\text { CL1 Neutrals - } \\
\quad \mathbf{N}=\mathbf{2 6 7}\end{array}$ & $\begin{array}{c}\text { CL2 } \\
\begin{array}{c}\text { Enthusiastics } \\
N=627\end{array}\end{array}$ & $\begin{array}{c}\text { CL3: } \\
\text { Price } \\
\text { sensitives } \\
\mathbf{N}=\mathbf{2 4 5} \\
\end{array}$ & $\begin{array}{c}\text { Total }-\mathrm{N}= \\
1139\end{array}$ \\
\hline & Mean & Mean & Mean & Mean \\
\hline Factor 1: Atmospherics & -0.304908 & 0.1555948 & -0.0659082 & \\
\hline Factor 2: Staff quality & -1.139306 & 0.238793 & 0.6304958 & \\
\hline Factor 3: Value for monev & -0.0747936 & 0.122779 & -0.2327043 & \\
\hline Factor 4: Product quality & -0.378158 & 0.2131835 & -0.1334607 & \\
\hline Factor 5: Satisfaction and intention to recommend & 0.0746205 & 0.463464 & -1.2674105 & \\
\hline The windows look good & 3.4 & 4.2 & 3.88 & 3.91 \\
\hline The lighting is appropriate and pleasant & 3.4 & 4.24 & 4 & 3.96 \\
\hline $\begin{array}{l}\text { The F\&B-related retailers have a good layout } \\
\text { (arrangement of space) }\end{array}$ & 3.32 & 4.17 & 3.85 & 3.87 \\
\hline The background music is pleasant & 3.16 & 3.84 & 3.34 & 3.54 \\
\hline The temperature is pleasant & 3.44 & 4.13 & 3.83 & 3.88 \\
\hline $\begin{array}{l}\text { The F\&B-related retailers have good standards of } \\
\text { cleanliness }\end{array}$ & 3.56 & 4.27 & 4.04 & 4.03 \\
\hline The scents that you breathe are pleasant & 3.46 & 4.12 & 3.79 & 3.86 \\
\hline The noise is tolerable & 3.4 & 3.97 & 3.55 & 3.72 \\
\hline $\begin{array}{l}\text { The signs (to identify areas of products, etc.) are } \\
\text { understandably }\end{array}$ & 3.2 & 4.1 & 3.61 & 3.74 \\
\hline $\begin{array}{l}\text { The aesthetic and architectural aspect of F\&B-related } \\
\text { retailers is pleasant and appealing }\end{array}$ & 3.33 & 4.21 & 3.77 & 3.87 \\
\hline $\begin{array}{l}\text { The F\&B-related retailers are made so as to effectively } \\
\text { manage the movement of people }\end{array}$ & 3.26 & 4.08 & 3.63 & 3.76 \\
\hline $\begin{array}{l}\text { The decoration inside the F\&B-related retailers } \\
\text { (colours, furniture, etc.) is pleasant and appealing }\end{array}$ & 3.31 & 4.18 & 3.82 & 3.86 \\
\hline $\begin{array}{l}\text { The staff responds to customer demand with accuracy } \\
\text { and reliability }\end{array}$ & 2.94 & 4.22 & 4.1 & 3.85 \\
\hline $\begin{array}{l}\text { The staff responds to customer inquiries in a timely } \\
\text { manner }\end{array}$ & 2.93 & 4.26 & 4.13 & 3.88 \\
\hline $\begin{array}{l}\text { The staff is present, available and can be easily } \\
\text { contacted }\end{array}$ & 2.97 & 4.23 & 4.18 & 3.89 \\
\hline $\begin{array}{l}\text { In general, the staff was courteous, polite and } \\
\text { respectful }\end{array}$ & 3.05 & 4.33 & 4.27 & 3.98 \\
\hline $\begin{array}{l}\text { The staff was able to communicate in a clear and } \\
\text { understandable manner in a foreign language }\end{array}$ & 3 & 4.24 & 4.09 & 3.87 \\
\hline $\begin{array}{l}\text { In general, the staff has an aesthetic and smart } \\
\text { appearance and dress }\end{array}$ & 3.24 & 4.39 & 4.26 & 4.06 \\
\hline $\begin{array}{l}\text { The staff showed competence (knowledgeable and } \\
\text { experienced) }\end{array}$ & 3.05 & 4.32 & 4.1 & 3.93 \\
\hline Prices are reasonable & 2.7 & 3.38 & 2.61 & 3.02 \\
\hline $\begin{array}{l}\text { Prices of food \& beverage of this airport are } \\
\text { competitive with other airports }\end{array}$ & 2.93 & 3.6 & 2.83 & 3.23 \\
\hline The products have a good quality/price ratio & 2.86 & 3.55 & 2.95 & 3.22 \\
\hline The selection of food $\&$ beverage is appropriate & 3.01 & 4.06 & 3.41 & 3.63 \\
\hline The quality of food and beverage is appropriate & 3.06 & 4.04 & 3.5 & 3.65 \\
\hline $\begin{array}{l}\text { Overall, I am satisfied with the food and beverage } \\
\text { services at this airport }\end{array}$ & 3 & 4.24 & 3.43 & 3.71 \\
\hline $\begin{array}{l}\text { I will speak well of the services of food and beverage } \\
\text { of this airport to family and friends offline }\end{array}$ & 2.86 & 4.26 & 2.01 & 3.32 \\
\hline $\begin{array}{l}\text { I will speak well of the services of food and beverage } \\
\text { of this airport to family and friends on social media } \\
\text { (Facebook, Twitter, Tripadvisor, etc.) }\end{array}$ & 2.76 & 4.11 & 1.61 & 3.12 \\
\hline
\end{tabular}


Table 4. Chi-square tests

Chi-square Sig.*

\begin{tabular}{lll} 
Gender & 2.955 & 0.228 \\
Age & 21.189 & $\mathbf{0 . 0 2 0 ^ { * }}$ \\
Marital status & 6.254 & 0.619 \\
Level of education & 30.328 & $\mathbf{0 . 0 0 1 ^ { \star * }}$ \\
Employment status & 29.855 & $\mathbf{0 . 0 1 9 ^ { * }}$ \\
Monthly household income & 13.230 & 0.104 \\
Number of trips per vear & 9.844 & $\mathbf{0 . 0 4 3 ^ { * }}$ \\
Number of fliahts per vear & 9.700 & $\mathbf{0 . 0 4 6 ^ { * }}$ \\
Purpose of travel & 0.385 & 0.825 \\
How lona before the fliaht did vou arrive at the airport? & 7.891 & 0.444 \\
Check-in modalitv & 18.450 & $\mathbf{0 . 0 0 0}$ \\
Place of residence & 4.141 & 0.387 \\
\hline
\end{tabular}

*Significant at the 0.05 level $-{ }^{*}$ Significant at the 0.01 level (significant values in bold)

have higher expectations than men (e.g. Lee, Cho and Ahn, 2012; Oh, Parks and Demicco, 2002). However, the fact that chi-square tests show that no significant differences exist between clusters in terms of gender seems to contradict prior studies (e.g. Martinelli, 2012), although they confirm others showing similar evidence (e.g. Del Chiappa, Giménez and Zapata-Aguirre, 2017). Our findings also confirm prior studies reporting women being particularly sensitive to prices and food quality (Martinelli, 2012) and atmospherics (Borges, Babin and Spielmann, 2013). In fact, the lowest scores in the items used to measure 'atmospherics', 'value for money' and 'product quality' were reported to exist for individuals belonging to 'neutrals' and 'price sensitives'-the two segments with the highest number of women. Furthermore, our study reporting employment status being able to significantly differentiate clusters confirms that of Del Chiappa Giménez and Zapata-Aguirre, (2017). Significant differences between segments were also found in terms of age, thus confirming the results of Del Chiappa, Martin and Román (2016) and Del Chiappa, Giménez and ZapataAguirre (2017). However, it needs to be mentioned that both these studies reported older travellers to be less satisfied with F\&B services at airports. On the contrary, in this study, the lesser satisfied segments ('neutrals' and 'price sensitive') were mostly composed by young travellers aged 18-34 years (neutrals: $46.6 \%$, price sensitive: $44.9 \%$ ) when compared to 'enthusiastics' (38.4), thus confirming Cao and Kim's (2015) study carried out in nonairport-based restaurants. This evidence could be explained by the observation that most individuals belonging to 'enthusiastics' are reported to travel and fly with a lower annual frequency (travelling, 1-4 times: 63.6\%, flying, 1-4 times: $70.6 \%$ ) compared to 'neutrals' (travelling, 1-4 times: $54.3 \%$, flying, 1-4 times: 62.8\%) and 'price sensitives' (travelling, 1-4 times: $63.0 \%$, flying, 1-4 times: $70.0 \%$ ). In other words, because of their overall lower frequency of travelling and flying, 'enthusiastic' folks could be less critical in judging F\&B services (e.g. Ha and Jang 2010; Severt, Tesone and Murmann, 2006; Tax, Brown and Chandrashekaran, 1998).

Quite interestingly, our study also found differences between clusters with regard to the way in which airport passengers were reported to undertake their check-in modalities (i.e. faceto-face versus online), an aspect that has never been be previously investigated in any studies on F\&B consumption and expenditure behaviour at airports. Specifically, our results show that airport-views towards different F\&B service features and their overall satisfaction 
were lower for 'neutrals' and 'price sensitives,'the two segments including mostly individuals checking-in face-to-face. This evidence could be explained by arguing that individuals checking-in face-to-face tend to arrive earlier at airports when compared to the time taken by their counterparts who do not queue at the check-in desk. Hence, 'neutrals' and 'price sensitives' would have the possibility to experience extended and prolonged service encounters. This, in turn, would offer them (i.e. 'neutrals' and 'price sensitives') the possibility of increasing their opportunities to interact with and be influenced by the different F\&B service features, thus resulting in more critical and experienced consumers.

\section{Conclusion}

Although non-aeronautical revenues worldwide, particularly those related to F\&B services, have experienced remarkable growth, research aimed at analysing airport travellers' perceptions towards the different aspects of F\&B and their satisfaction and behavioural intentions is still in its early stages (e.g. Del Chiappa, Martin and Román 2016; Del Chiappa, Giménez and Zapata-Aguirre, 2017, Martinelli, 2012). Further, to the best of our knowledge, there has been just one study (Del Chiappa, Giménez and Zapata-Aguirre, 2017) aimed at profiling travellers' perceptions and satisfaction pertaining to airport-related F\&B services. However, the number of $F \& B$ service features considered in this case was limited, as was the number of socio-demographic features and travel-related variables that were investigated as factors being potentially able to discriminate between different clusters. No attention was paid to flight-related variables (e.g. check-in modality and arrival time at the airport before the flight departure). Therefore, this study broadens the scientific debate surrounding the topic, thus answering recent calls for further research aimed at deepening our understanding about airport travellers' consumption behaviours (e.g. Graham, 2008), enlarging the number of socio-demographic features in particular, along with travel- and flight-related variables considered as being potential moderating factors of F\&B consumption behaviours at airports.
Overall, the findings reveal that airport travellers have a positive view towards F\&B services in term of atmospherics, staff quality and product quality, while some concerns exist in terms of perceived value for their money. On the whole, the overall satisfaction regarding F\&B offerings is slightly positive, while respondents do not appear to be particularly willing to recommend airport $F \& B$ to others overall, especially online.

However, cluster analysis applied to the scores of the four factors identified through the exploratory factor analysis ('atmospherics,' 'staff quality,' 'products quality,' 'value for money' and 'satisfaction and behavioural intentions') showed that airport travellers perceptions, satisfaction and behavioural intentions are not homogenous. Specifically, three clusters were identified: 'enthusiastics,' 'price sensitives' and 'neutrals,' with 'enthusiastics' being the biggest segment. According to research on restaurant experience (e.g. Hurst, 1970; Pugh, 2001), this study highlights that cleanliness and comfort, staff responsiveness and courtesy and speed of service (Pratten, 2004) need to be considered as key attributes in shaping airport satisfaction with F\&B services (Bogicevic et al., 2013; Del Chiappa, Giménez and Zapata-Aguirre, 2017). The results confirmed that in airport-related F\&B services, significant differences between the clusters were reported on the basis of certain socio-demographic features (i.e. age, level of education, employment status), travelrelated aspects (i.e. yearly frequency of travel) and flight-related variables (yearly frequency of flying and check-in modality). However, no significant differences were found in terms of gender, marital status, monthly household income, place of residence, purpose of travelling and arrival time at the airport before flight departure.

For example, 'neutrals' and 'price sensitives' were reported to be more likely women and youngsters, with higher frequency of travelling and flying, particularly sensitive to prices, food quality and atmospherics and having lower scores in terms of overall satisfaction and behavioural intentions, thus supporting prior studies (e.g. Borges, Babin and Spielmann, 2013; Cao and Kim, 2015; Lee et al., 2012; 
Martinelli, 2012). Our results reveal no significant differences in terms of gender, contradicting some prior studies (e.g. Martinelli, 2012), while confirming others (e.g. Del Chiappa, Giménez and Zapata-Aguirre, 2017), indicating that future studies in different airports and geographical circumstances are needed to be carried out in an attempt to further confirm the robustness of the insights offered in existing literature devoted to analysing airport travellers' behaviours towards F\&B services at airports. Furthermore, our findings contribute completely new knowledge to the extant literature, revealing that significant differences exist between clusters in terms of check-in modality, with airport travellers checking-in face-to-face having less positive views towards F\&B services at airports and being less satisfied compared to their counterparts checking-in online.

These conclusions are significant for both researchers and hospitality managers. On the one hand, they provide further insights into the scientific debate on passengers' consumption behaviours pertaining to F\&B services in airport areas, widening the number of both F\&Brelated service features and socio-demographic and travel- and flight-related variables that can be considered as potential moderating factors of airport travellers' perceptions, satisfaction and behavioural intentions. Furthermore, the fact that our findings confirmed some prior studies while rejecting others adds to the body of knowledge by highlighting the evidently inconsistent relationship between airport travellers' views, satisfaction and behavioural intentions and their socio-demographic features, along with travel- and flight-related variables. Finally, to the best of our knowledge, this study is the first study showing that the check-in modality (i.e. face-to-face versus online) is a moderating factor that needs to be considered when studying passengers consumption behaviours with respect to airportbased F\&B services.

On the other hand, these findings provide airport managers and airport-based retail managers with information that may be used to effectively manage their offerings and service design. First, they suggest that effort should be made to recognise nuances in the way airport travellers consume products and services, thus assessing F\&B services on the basis of their socio-demographic features, plus travel- and flight-related characteristics, so that overall retail services may be designed to better reflect the characteristics of their target consumers. Thus, for example, airport managers and airport-based retail managers should invest in continuous improvement of their offerings (in terms of atmospherics, staff quality and product quality) to meet the expectations of women and experienced travellers and/or to push the price/quality ratio higher when dealing with younger folk. Doing so would, in turn, contribute to capturing the travellers' preferences and expectations, making them more satisfied, and more prone to talk positively about the F\&B offerings at the airport (Moon, Yoon and Han, 2017). In this direction, it would be also certainly useful to consider the findings from this study as useful in initiating a tracking process aimed at assessing the extent to which marketing and promotion activities actually contribute to enhancing airport travellers' satisfaction with F\&B services. Furthermore, the fact that some segments (i.e. 'enthusiastics,' and, particularly, 'price sensitives') were reported not to be particularly prone to spread e-WOM about F\&B services, despite being satisfied with the F\&B offerings, suggests that airport and retail managers should proactively incentivise their customers to post a comment or review online. In doing so, airport managers and retailers could use modern reputation management systems that first ask their customers to assess their satisfaction towards their experience with $F \& B$ services at airports and then ask just those customers providing assessments falling in a positive range to post a comment and review. Finally, our results suggest that airport and airline managers should keep their attention focused when deciding to incentivise their customers who check-in online. In fact, on the one hand, incentivising passengers to check-in online can certainly contribute to reduce queuing time both at traditional check-in points and when going through security, thereby increasing passengers' satisfaction and contributing to reducing the number of employees needed to manage traditional check-ins. However, our results suggest that airport travellers who check-in online are 
usually less positive in their views, satisfaction and intention to recommend the airport-based F\&B services to others. That said, airport managers and airline managers should decide to incentivise web check-in after comparing the costs and benefits of both alternatives (traditional and web-based check-in), carefully considering the effect that the different check-in modalities exert.

In spite of the theoretical and managerial contributions, this study is not free of limitations. First, the study used a sample which is highly site-specific (i.e. data was collected at one and not multiple airports) and not representative of the overall population under investigation (i.e. airport travellers at the Olbia-Costa Smeralda Airport). These circumstances render our findings hardly generalisable. In the future, it would be useful to repeat the study at other airports and geographical circumstances to further confirm the robustness of our results. Second, although this study considered a wider number of variables that could moderate airport travellers' perceptions, satisfaction and behavioural intentions towards F\&B services, other variables remained unexplored (e.g. travel party size, personality traits, emotions exuded and prior experience in using F\&B services at the airport selected as research setting); these variables can be taken into account in future research. Furthermore, our study did not investigate passengers' consumption behaviour towards different types of F\&B services that currently exist at the airport (e.g. bars, fast food joints, restaurants and pizzerias). This outcome occurred despite the fact that previous restaurant-related studies show that consumer perception, values and satisfaction differ based on the type of restaurant experienced (e.g. Ha and Jang, 2013). Hence, future studies could consider the possibility of investigating passengers' perceptions, satisfaction and behavioural intentions towards different types of F\&B retailers at the airport. The third limitation is conveyed by the fact that it is difficult to confirm all retailers' features in detail. This fact, in turn, makes it difficult to explain the reason why certain airport travellers were reported to express the given levels of satisfaction or dissatisfaction. Therefore, future studies can consider the possibility of conducting a qualitative study (or a mixedmethod study-perhaps an explanatory mixedmethod approach) to gain a more comprehensive understanding and explanation about what exactly was satisfying and unsatisfying for airport travellers and what they would have liked to have experienced in order to have been more satisfied. For example, rather than simply knowing that certain passengers were dissatisfied with certain service features (e.g. the retail layout, the interior design and the staff dress code and appearance.) it would be more useful to know how they would have liked to see those service features (e.g. how the retail layout should have been or the interior design and how the staff might manage their remarks and body language to be perceived as politer). This amelioration will allow us to be more effective in contributing to a further development in the current body of knowledge devoted to analysing travellers' shopping behaviours in airports; in addition, it will provide even more pragmatic and detailed suggestions to airport managers and retailers wanting to increase the satisfaction level in their target markets.

\section{References}

$\mathrm{ACl}$ - Airports Council International (2017). Annual World Airport Traffic Forecasts (WATF) 2016-2040. URL:https://aci.aero/ Media/9d12ed0c-e36b-48da-9b9f-8ec4

640d5821/iM0Zyg/ Statistics\%20and\% 20Data/Infographics/Infographic ACI Wor Id Airport Traffic Forecasts\%202017\%E 2\%80\%932040.pdf (Accessed on 4 August 2018).

ACI - Airports Council International. (2015). $2015 \mathrm{ACl}$ airport economics report. URL: http://www.aci.aero/Publications/Full-Publi cations-Listing/2015-ACl-Airport-Economi cs-Report (Accessed on 10 August 2018).

ACI (2017). Annual World Airport Traffic Forecasts - WATF. URL: file://C:/Users/ User/Downloads/Infographic_ACI_World Airport_Traffic_Forecasts $\% 202017 \%$ E2\% 80\%932040.pdf (Accessed on 4.08.2018).

Appold, S. J., \& Kasarda, J. D. (2006). The appropriate scale of US airport retail activities. Journal of Air Transport Management, 12(6), 277-287.

Babin, B. J., Darden, W. R., \& Griffin, M. (1994). Work and/or fun: Measuring 
hedonic and utilitarian shopping value. Journal of Consumer Research, 20(4), 644-656.

Ballantine, P. W. (2005). Effects of interactivity and product information on consumer satisfaction in an online retail setting. International Journal of Retail \& Distribution Management, 33(6), 461-471.

Ballantine, P. W., Jack, R., \& Parsons, A. G. (2010). Atmospheric cues and their effect on the hedonic retail experience. International Journal of Retail \& Distribution Management, 38(8), 641-653.

Bogicevic, V., Yang, W., Cobanoglu, C., Bilgihan, A., \& Bujisic, M. (2016). Traveler anxiety and enjoyment: The effect of airport environment on traveller's emotions, Journal of Air Transport Management, 57, 122-129.

Borges, A., Babin, B. J. \& Spielmann, N. (2013). Gender orientation and retail atmosphere: effects on value perception. International Journal of Retail \& Distribution Management, 41(7), 498-511.

Cao, Y., \& Kim, K. (2015). How do customers perceive service quality in differently structured fast food restaurants? Journal of Hospitality Marketing \& Management, 24(1), 99-117.

Castillo-Manzano J. I., \& López-Valpuesta L. (2013). Analysing passenger behaviour towards the catering industry: Implications for airport management. International Journal of Hospitality Management, 35: 258-260.

Castillo-Manzano, J. I. (2010). Determinants of commercial revenues at airports: lessons learned from Spanish regional airports. Tourism Management, 31(6), 788-796.

Chen, J. K. C, Batchuluun, A., \& Batnasan J., (2015). Services innovation impact to customer satisfaction and customer value enhancement in airport. Technology in Society, 43, 219-230.

Choi, M., Law, R., \& Heo, C. Y. (2018). An Investigation of the Perceived Value of Shopping Tourism. Journal of Travel Research, 17(7), 962-980.

Chung, Y. S. (2015). Hedonic and utilitarian shopping values in airport shopping behavior. Journal of Air Transport Management, 49, 28-34.
Correia, A., \& Kozak, M. (2016). Tourists' shopping experiences at street markets: Cross-country research. Tourism Management, 56, 85-95.

Crawford, G., \& Melewar, T. C. (2003). The importance of impulse purchasing behaviour in the international airport environment. Journal of Consumer Behaviour, 3(1), 85-98.

Cronin Jr, J. J., \& Taylor, S. A. (1992). Measuring service quality: a reexamination and extension. The Journal of Marketing, 56(3), 55-68.

Del Chiappa, G., Giménez, M., \& ZapataAguirre, S. (2017). Travelers Satisfaction with Food and Beverage Services in Airports. Journal of Hospitality Marketing and Management, 26(8), 829-845.

Del Chiappa, G., Martin, J. C., \& Román, C. (2016). Service quality of airports' food and beverage retailers. A fuzzy approach. Journal of Air Transport Management, 53, 105-113

Doganis, R. (1992). The Airport Business. London: Routledge.

Doong, H. S., Wang, H. C., \& Law, R. (2012). An examination of the determinants of in-flight duty-free shopping: Hedonic and utilitarian motivations. International Journal of Tourism Research, 14(3), 303-306.

Echevarne, R. (2008). The impact of attracting low-cost carriers to airports. In: Graham A., Papatheodouru A., Forsyth P. (Eds.). Aviation and tourism. Hampshire: Ashgate Publishing.

Entwistle, M. (2007). Customer service and airport retail: stimulate passenger spending. Journal of Airport Management, 1(2), 151-157.

Fasone, V., Kofler, L., \& Scuderi, R. (2016). Business performance of airports: Nonaviation revenues and their determinants. Journal of Air Transport Management, 53, 35-45.

Gallarza, M. G., Fayos Gardó, T., \& Calderón García, H. (2017). Experiential tourist shopping value: Adding causality to value dimensions and testing their subjectivity. Journal of Consumer Behaviour, 16(6), 76-92.

Geuens, M., Vantomme, D., \& Brengman, M. (2004). Developing a typology of airport 
Profiling airport travellers based on their perceptions, satisfaction and intention to recommend food and beverage services.

shoppers. Tourism Management, 25(5), 615-622.

Graham, A. (2008). Managing Airports: An International Perspective, (3 ${ }^{\text {rd }}$ ed.). Oxford: Butterworth Heinemann-Elsevier.

Graham, A. (2009). How important are commercial revenues to today's airports? Journal of Air Transport Management, 15(3), 106-111.

Ha, J., \& Jang, S. (2013). Attributes, consequences, and consumer values: A means-end chain approach across restaurant segments. International Journal of Contemporary Hospitality Management, 25(3), 383-409.

Ha, J., \& Jang, S. S. (2010). Perceived values, satisfaction, and behavioral intentions: The role of familiarity in Korean restaurants. International Journal of Hospitality Management, 29(1), 2-13.

Hair, J. F., Black, W. C., Babin, B. J., \& Anderson, R. E. (2010). Multivariate data analysis: A global perspective, (7th ed.). New Jersey, NJ: Pearson.

Halpern, N., \& Graham, A. (2003). Airport Marketing. London: Routledge.

Han, H., Yu, J., \& Kim, W. (2018). Airport shopping - an emerging non-aviation business: triggers of traveler loyalty. Journal of Travel \& Tourism Marketing, 35(7), 835-845.

Han, S., Ham, S., Yang, I., \& Baek, S. (2012). Passengers' perceptions of airline lounges: Importance of attributes that determine usage and service quality measurement. Tourism Management, 33 (5), 1103-1111.

Heung, V. C., Wong, M. Y., \& Qu, H. (2002). A study of tourists' satisfaction and postexperience behavioral intentions in relation to airport restaurant services in the Hong Kong SAR. Journal of Travel \& Tourism Marketing, 12(2-3), 111-135.

Holbrook, M. B., \& Hirschman, E. C. (1982). The Experiential Aspects of Consumption: Consumer Fantasies, Feelings, and Fun. Journal of Consumer Research, 9(2), 132140.

Hurst, M. E. (1970). You sell more than food. Cornell Hotel and Restaurant Administration Quarterly, 11(1), 103-112.

Jarach, D. (2001). The evolution of airport management practices: towards a multi- point, multi-service, marketing-driven firm. Journal of Air Transport Management, 7(2), 119-125.

Johnston, R. (1995). The determinants of service quality: satisfiers and dissatisfiers. International Journal of Service Industry Management, 6(5), 53-71.

Jones, M. A., \& Reynolds, K. E. (2006). The role of retailer interest on shopping behavior. Journal of Retailing, 82(2), 115126.

Kim, E. J., \& Geistfeld, L. (2003). Consumers' Restaurant Choice Behavior and the Impact of Socio-Economic and Demographic Factors. Journal of Foodservice Business Research, 6(1), 2-24.

Lam, W. H., Tam, M. L., Wong, S. C., \& Wirasinghe, S. C. (2003). Wayfinding in the passenger terminal of Hong Kong International Airport. Journal of Air Transport Management, 9(2), 73-81.

Lee, C. K., Lee, Y. K., \& Wicks, B. E. (2004). Segmentation of festival motivation by nationality and satisfaction. Tourism Management, 25(19), 61-70.

Lee, T. J., Cho, H., \& Ahn, T. H. (2012). Senior citizen satisfaction with restaurant service quality. Journal of Hospitality Marketing \& Management, 21(2), 215-226.

Lin, I. Y., \& Mattila, A. S. (2010). Restaurant servicescape, service encounter, and perceived congruency on customers' emotions and satisfaction. Journal of Hospitality Marketing \& Management, 19(8), 819-841.

Lin, Y. H., \& Chen, C.F. (2013). Passengers' shopping motivations and commercial activities at airports $e$ the moderating effects of time pressure and impulse buying tendency, Tourism Management, 36, 426-434.

Lo, A., \& Qu, H. A (2015). A theoretical model of the impact of a bundle of determinants on tourists' visiting and shopping intentions: A case of mainland Chinese tourists. Journal of Retailing and Consumer Services, 22, 231-243.

Lu, Y. (2014). Investigating factors that influence passengers' shopping intentions at airports: Evidence from Taiwan. Journal of Air Transport Management, 35, 72-77.

Martinelli, E. (2012). La domanda di ristorazione per il/in movimento: 
Specificità di formato e di servizio richieste dalla clientela [Consumer demand for restaurant services in transit area: an analysis by retail format and consumer expectation]. Micro \& Macro Marketing, 2, 289-304.

Moon, H., Yoon, H. J., \& Han, H. (2017). The effect of airport atmospherics on satisfaction and behavioral intentions: testing the moderating role of perceived safety. Journal of Travel \& Tourism Marketing, 34(6), 749-763.

Murphy, L., Moscardo, G., Benckendorff, P., \& Pearce, P. (2011). Evaluating tourist satisfaction with the retail experience in a typical tourist shopping village. Journal of Retailing and Consumer Services, 18(4), 302-310.

Namin, A. (2017). Revisiting customer perception of service quality in fast food restaurants. Journal of Retailing and Consumer Services, 34, 70-81.

Newman, S., \& Lloyd Jones, T. (1999). Airport and travel terminal retailing: Strategies, trends and market dynamics. London: Ravenfox Publishing.

Oh, H., Parks, S. C., \& Demicco, F. J. (2002). Age and gender-based market segmentation. International Journal of Hospitality \& Tourism Administration, 3(1), 1-20.

Omar, O., \& Kent, A. (2001). International airport influences on impulsive shopping: Trait and normative approach. International Journal of Retail \& Distribution Management, 29(5), 226-235.

Perng, S. W., Chow, C. C., \& Liao, W. C. (2010). Analysis of shopping preference and satisfaction with airport retailing products. Journal of Air Transport Management, 16, 279-283.

Pizam, A., \& Ellis, T. (1999). Customer satisfaction and its measurement in hospitality enterprises. International Journal of Contemporary Hospitality Management, 11(7), 326-339.

Popovic, V., Kraal, B., \& Kirk, P. (2010). Towards airport passenger experience models. Paper presented at the Proceedings of 7th International Conference on Design \& Emotion, Chicago, Illinois.
Pratten, J. D. (2004). Customer satisfaction and waiting staff. International Journal of Contemporary Hospitality Management, 16(6), 385-388.

Pugh, S. D. (2001). Service with a smile: Emotional contagion in the service encounter. Academy of Management Journal, 44(5), 1018-1027.

Rowley, J., \& Slack, F. (1999). The retail experience in airport departure lounges: reaching for timelessness and placelessness. International Marketing Review, 16(4/5), 363-376.

Sacerdote, E. (2009). Travel retailing: Analisi, strategie, best practices. Milano: Franco Angeli.

Seddighi, H. R., Nutall, M. W., \& Theocharous, A. L. (2001). Does cultural background of tourists influence the destination choice? An empirical study with special reference to political instability. Tourism Management, 22(2), 181-191.

Severt, D., Tesone, D., \& Murrmann, S. (2006). Prior experience satisfaction and subsequent fairness perceptions within the service experience. Journal of Hospitality \& Leisure Marketing, 13(3-4), 121-137.

Shamma, H., \& Hassan, S. (2013). Customerdriven benchmarking: A strategie approach toward a sustainable marketing performance. Benchmarking: An International Journal, 20(3), 377-395.

Sirakaya-Turk, E., Ekinci, Y., \& Martin, D. (2015). The efficacy of shopping value in predicting destination loyalty. Journal of Business Research, 68(9), 1878-1885.

Sweeney J., \& Soutar G. (2001). Consumer perceived value: the development of a multiple item scale. Journal of Retailing, 77(2), 203-207.

Tax, S. S., Brown, S. W., \& Chandrashekaran, M. (1998). Customer evaluations of service complaint experiences: implications for relationship marketing. The Journal of Marketing, 60(2), 60-76.

The Moodie Report (2014). The importance of the F\&B industry, FAB and The Foodie Report. URL: http://www.moodiereport. com/document.php?c id $=1124 \&$ doc id $=2$ 9126 http://www.moodiereport.com/docu 
Profiling airport travellers based on their perceptions, satisfaction and intention to recommend food and beverage services.

ment.php?c id=1124\&doc id=29126

(Accessed on 12 March, 2014).

Torres, E. N. (2014). Deconstructing service quality and customer satisfaction: Challenges and directions for future research. Journal of Hospitality Marketing \& Management, 23(6), 652-677.

Torres, E., Dominguez, J. S., Valdés, L., \& Aza, R. (2005). Passenger waiting time in an airport and expenditure carried out in the commercial area. Journal of Air Transport Management, 11, 363-367.

Turley, L. W. \& Milliman, R. E. (2000). Atmospheric effects on shopping behavior: a review of the experimental evidence. Journal of Business Research, 49(2), 193-211.

UNWTO - World Tourism Organization (2017). Tourism Highlights. URL: https://www.eunwto.org/doi/pdf/10.18111/97892844190 29 (Accessed on 25.08.2018).

Wattanacharoensil, W., Schuckert, M., \& Graham, A. (2016). An airport experience framework from a tourism perspective. Transport reviews, 36(3), 318-340.
Wattanacharoensil, W., Schuckert, M., Graham, A., \& Dean, A. (2017). An analysis of the airport experience from an air traveler perspective. Journal of Hospitality and Tourism Management, 32, 124-135.

World Travel and Tourism Council - WTTC. (2018). Monthly economic impact. URL: https://www.wttc.org/economicimpact/monthly-updates/\#undefined (Accessed on 08.08.2018).

Yokomi, M., Wheat, P., \& Mizutani, J. (2017). The impact of low-cost carriers on nonaeronautical revenues in airport: An empirical study of UK airports. Journal of Air Transport Management, 64, 77-85.

Zaltman, G., LeMasters, K., \& Heffring, M. (1982), Theory construction in Marketing. Some Thoughts. New York, John Wiley \& Sons. Inc.

Zeithaml, V. A., Bitner, M. J., \& Dremler, D. (1996). Services Marketing. New York, NY: McGraw Hill.

Zhou, L. (2004). A dimension-specific analysis of performance-only measurement of service quality and satisfaction in China's retail banking. Journal of Services Marketing, 18(7), 534-546. 